\title{
Technical and functional aspects of enforcement of natural fertilizer warehouses in respect of environmental protection
}

\author{
KRZYSZTOF WIŚNIEWSKI, AGATA PAWŁAT-ZAWRZYKRAJ \\ Department of Civil Engineering, Warsaw Agricultural University - SGGW
}

\begin{abstract}
Technical and functional aspects of enforcement of natural fertilizer warehouses in respect of environmental protection. The article raises issues related to the implementation and use of manure storage facilities in aspect of environmental protection. Authors take into account two main factors affecting the proper functioning of the manure storage facilities: technical and functional ones. In case of the technical aspects of implementation and use of manure storage facilities it is essential to respect the principles of BAT. However, in the case of the functional aspects the main factor is compliance with Polish and European Union regulations.
\end{abstract}

Key words: dunghill, liquid manure tanks, manure disposal, manure storage, mechanization level, functionality index.

\section{INTRODUCTION}

Method of manure storage in liquid (slurry, manure) or solid form (manure) is very significant in terms of environmental protection. Improperly located warehouses and stored manure cause pollution of groundwater with excessive amount of nitrates, phosphate, sodium and potassium. Pollution of land adjacent to the manure storage facilities, as well as underground waters can also be caused by improperly made (leaky), damaged dunghills and tanks of liquid manure. Therefore, manure storage method be- comes particularly important in terms of environmental protection and must meet requirements set by the Polish and the EU legislation

Two directives concern an issue of environmental impact of manure storage facilities: Council Directive (91/676/EEC) of 12 December 1991 concerning the protection of waters against pollution caused by nitrates from agricultural sources and Council Directive (96/61/EC) of 24 September 1996 concerning integrated pollution prevention and control.

According to Council Directive 91/676/ EEC of 12.12.1991, manure means waste products excreted by livestock or a mixture of litter and waste products excreted by livestock, even in processed form. The Directive obliges member-states to apply a code of good agricultural practices.

Polish regulations have been specified in recent times and are compatible with EU directives. In accordance with the Act on fertilizers and fertilization (DzU $2007 \mathrm{nr} 147$ poz. 1033) Natural fertilizers in solid form should be stored in inventory rooms or on impermeable plates, protected against penetration of leakage into the ground and equipped with installation to carry out leaks into tight tanks (Wierzbicki et al. 2002). 
The Council Directive (96/61/EEC) of 24 September 1996 concerning integrated pollution prevention and control does not provide specific techniques or technologies to prevent or reduce emissions. It obliges to take all appropriate tools to combat environmental pollution, particularly by the application of Best Available Techniques (BAT).

BAT should be used in animal housing systems, manure storage facilities, processing of farm fertilizers and their use on cultivated land. In general, in case of manure storage BAT include:

- design of manure storage facilities with sufficient capacity, the required capacity depends on climatic conditions and length of periods when fertilization of fields is not possible,

- construction of a concrete plate with an outflow system and an effluent tank for all permanent manure storage units,

- location of any newly constructed manure storage areas in such a place where they will be the least arduous to the surroundings, taking into account the distance between the magazine and neighboring property (the building law and technical conditions) and the prevailing wind direction (Wardal and Głaszczka 2005).

During the design and construction of manure plates (dunghills), the following factors should be considered:

- amount of manure produced,

- a method used to remove manure from a livestock building,

- a method used to collect manure from a manure plate when it is moved to the field,

- soil and water conditions.

Soil-water conditions affect the durability of manure plate construction and proper protection against the negative impact of low temperatures. Therefore, it is necessary to carry out the geotechnical testing at the design stage in order to establish the conditions of soil and water needed for proper sizing in terms of design and functionality. The diagnosis of geotechnical conditions also allows you to design an effective drainage, soil stabilization and other procedures affecting the durability and tightness of the manure plate itself, as well as diffe-

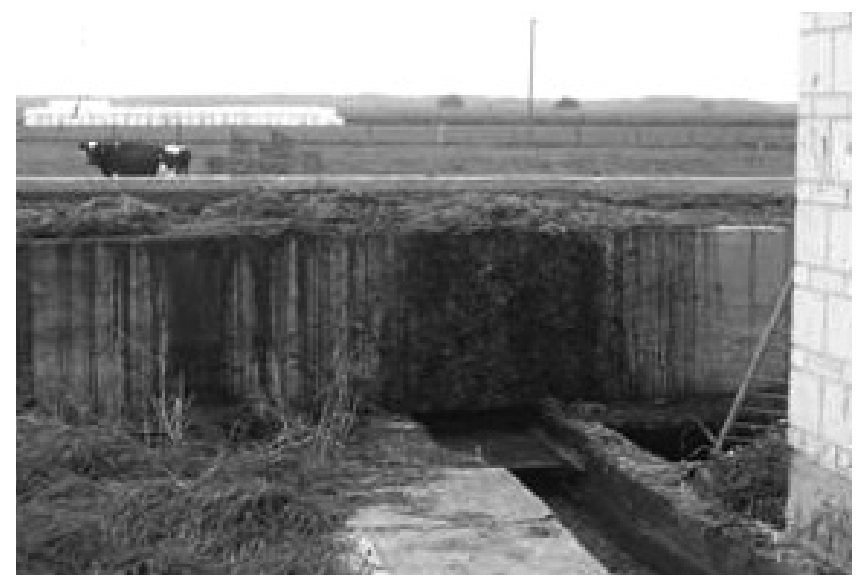

FIGURE 1. The manure board with a very small capacity (photo: K. Wiśniewski) 


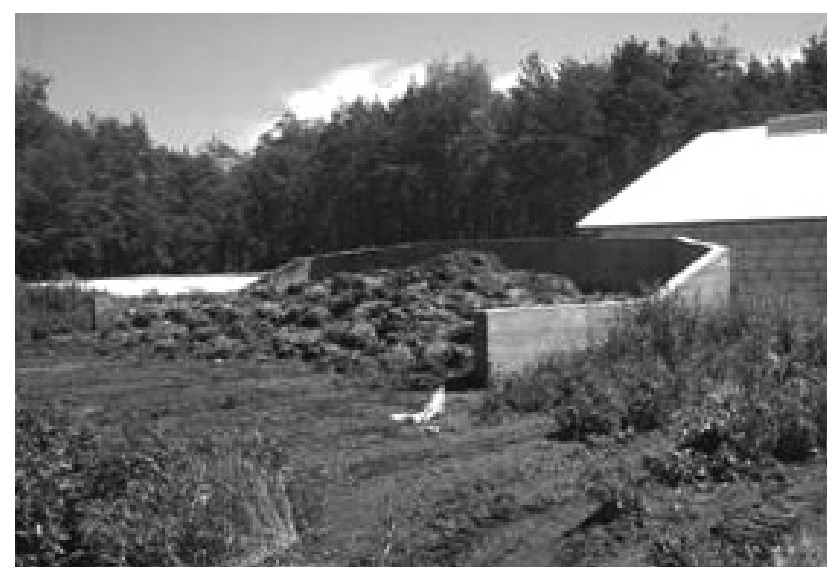

FIGURE 2. The dunghill with inappropriate discharge of leachate into the tank and the lack of adequate protection zone (photo: K. Wiśniewski)

rent solutions of dunghills construction such as a separate tank or a tank located beneath a manure plate.

Proper sizing of the dunghill allows secure storage of manure for a period of 6 months (Wiśniewski 2008). Too small manure plate after a short period of utilization leads to a similar situation such as forbidden storage of manure on the ground. In addition, it is difficult to collect the entire fertilizer and soil contaminated by it without collecting the ground of the driveway and damaging edges of the plate. It can also cause manure runoff or leaching out of the dunghill (Figs $1,2)$. In the long run, depending on the period of use and type of subsoil, it can lead to pollution (contamination) of adjacent land and groundwater.

\section{RESEARCH METHODOLOGY}

The main objective of the study was to evaluate systems of removing and storing manure in free-stall cattle barns and their impact on the environment. Scope of work included the study of procedures used for removal and storage of manure applied in 10 free-stall cattle houses on farms engaged in milk production. The concentration of animals in the analyzed barns ranged from 44 to 124 heads [LSU - Livestock Unit].

As a criterion for assessing the functional and technical solutions for removing and storing of manure, two indicators were used: the level of mechanization and the index of functionality.

On the basis of the collected material, the index of functionality of the barns, as well as the mechanization level of the procedure were determined.

The necessary statistical calculations were needed to evaluate the impact of functional and technological solutions on energy consumption of manure removal and storage and the relationship between them. The calculations were made by using the method of least squares and simple, power and exponential regression coefficients. In this study, there following coefficients were defined: correlation coefficients $(r)$, the degree of significance $(p)$, the level of probability using the 
t-test - Student's standard error of estimation determining the degree of deviation from the calculated regression using the computer software Statgraphics plus. Version 4.0.

Functionality index $\boldsymbol{W}_{\boldsymbol{f}}$ - it was identified by using the author's method (Wiśniewski 2007) based on the literature (Romaniuk 1996; Fiedorowicz 1998) regarding the following features:

$B_{L Z}$ - safety and working conditions of people and animals,

$O_{\dot{s}}-$ environmental protection,

$U_{o}$ - arduousness of service,

$D_{z}-$ livestock welfare.

$$
W_{f}=\frac{\left(B_{L Z}+O_{s}+U_{o}+D_{z}\right)}{4}
$$

Individual features were rated on a scale $0-10$ pts. according to the criteria set out in the Table 1.

The evaluation of functionality of littered cattle barns was based on the criteria presented in Table 1. The assessment was made by three independent observers in order to avoid errors associated with subjective method of awarding points for particular features affecting the functionality index $W_{f}$.

The mechanization level of removal and storage of animal wastes were determined according to the methodology of Romaniuk (1996) and Fiedorowicz (1998), based on the total daily amount of human labor per treatment of manure disposal for a single cow (Tables 2 and 3).

According to Fiedorowicz (1998)

$$
w_{m}=\frac{E_{m}+E_{n}}{E_{\dot{z}}+E_{m}+E_{n}} \cdot 100 \%
$$

According to Romaniuk (1996)

$$
w_{m}=\frac{E_{m}}{E_{c}} \cdot 100 \%
$$

$E_{n}$ - energy derived from the energy carrier [MJ],

$E_{c}$ - total energy [MJ],

$E_{\dot{z}}-$ energy equivalent of human labor $[\mathrm{MJ}]$,

$E_{s}$ - energy contained in the materials and raw materials $[\mathrm{MJ}]$,

$E_{m}$ - energy contained in machines and equipment [MJ],

TABLE 1. Criteria for assessing the functionality of the studied objects (Romaniuk 1996, Fiedorowicz 1998)

\begin{tabular}{|l|r|c|}
\hline Descriptive scores & Scores & $\begin{array}{c}\text { Functionality index } \\
W_{f}\end{array}$ \\
\hline Excellent & 10 & 1.0 \\
\hline Very good - no objections & 9 & 0.9 \\
\hline Very good - little objections & 8 & 0.8 \\
\hline Quite good - many advantages & 7 & 0.7 \\
\hline Good - more advantages than disadvantages & 6 & 0.6 \\
\hline Good enough - equal amount of advantages and disadvantages & 5 & 0.5 \\
\hline Satisfactory - many disadvantages and a few advantages & 4 & 0.4 \\
\hline Satisfactory - disqualifying disadvantages and few advantages & 3 & 0.3 \\
\hline Inadequate & 2 & 0.2 \\
\hline Totally inadequate & 1 & 0.1 \\
\hline
\end{tabular}


$E_{b}$ - energy contained in buildings and structures associated with removal and storage of manure $[\mathrm{MJ}]$.

TABLE 2. Criteria for evaluating the mechanization level of the cattle-barns (Fiedorowicz 1998)

\begin{tabular}{|c|c|}
\hline $\begin{array}{c}\text { Mechanization } \\
\text { indicator } w_{m}\end{array}$ & $\begin{array}{c}\text { Mechanization } \\
\text { level } P_{m}\end{array}$ \\
\hline$<70$ & 1 \\
\hline $70-75$ & 2 \\
\hline $75-80$ & 3 \\
\hline $80-85$ & 4 \\
\hline$>85$ & 5 \\
\hline
\end{tabular}

TABLE 3. Criteria for evaluating the mechanization level of the cattle-barns (Romaniuk 1996).

\begin{tabular}{|c|c|c|}
\hline \multicolumn{2}{|c|}{ 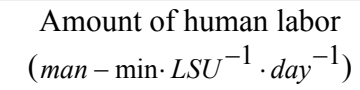 } & \multirow[t]{2}{*}{$\begin{array}{l}\text { Mechanization } \\
\text { level } P_{m}\end{array}$} \\
\hline Conventional & Used & \\
\hline$<16$ & $<2.05$ & 1 \\
\hline $16-11$ & $2.05-1.41$ & 2 \\
\hline $11-8$ & $1.41-1.05$ & 3 \\
\hline $8-4$ & $1.05-0.52$ & 4 \\
\hline$<4$ & $<0.52$ & 5 \\
\hline
\end{tabular}

\section{RESEARCH RESULTS}

The values of the evaluation of individual features and functionality index based on the methodology of research are presented in the Table 4.

The analyzed cattle-barns are characterized by a high score of functionality index in terms of disposal and manure storage treatments and were rated very good (the average value of the functionality coefficient for all the barns was $W f=$ $=0.822$ ). Eight out of ten barns covered by the survey received a very good score with no objections (barns nr 1, 2, 4, 5, 6, 7, $9,10)$ - the functionality index for these barns was $W f>0.80$. Outstanding two barns received very good grade with small objections (0.8), and the functionality index value ranged $0.70<W f$ $<0.80$. In case of the barns with the highest functionality index, safety and working conditions were rated the highest - ranging from 8 to 9 points (max. 10 ), environmental protection (pollution

TABLE 4. Scoring and functional index $W_{f}$ of the studied barns in the treatment of removal and storage of natural fertilizers (Wiśniewski 2007)

\begin{tabular}{|l|c|c|c|c|c|c|l|}
\hline \multirow{2}{*}{ Cattle-barn } & \multicolumn{5}{|c|}{$\begin{array}{c}\text { Scores for individual features } \\
\text { (0-10 pts) }\end{array}$} & \multirow{2}{*}{$W_{f}$} & Descriptive scores \\
\cline { 2 - 7 } & $B_{L Z}{ }^{1)}$ & $O_{S}^{2)}$ & $U^{3)}$ & $D^{4)}$ & $\begin{array}{c}\text { Average } \\
\text { score }\end{array}$ & & \\
\hline 1. Tranzbór & 9 & 8.5 & 8 & 9 & 8.625 & 0.86 & Very good no objections \\
\hline 2. Tranzbór & 8 & 8 & 8 & 8 & 8.0 & 0.80 & Very good no objections \\
\hline 3. Bobino-Grzybki & 7 & 7 & 8 & 8 & 7.5 & 0.75 & Very good little objections \\
\hline 4. Bożenica & 9 & 9 & 8 & 8 & 8.5 & 0.85 & Very good no objections \\
\hline 5. Załuski Lipniewo & 8 & 8 & 8 & 8 & 8.0 & 0.8 & Very good no objections \\
\hline 6. Kąty Wielgi & 9 & 7 & 8 & 8 & 8.0 & 0.80 & Very good no objections \\
\hline 7. Żeszczynka & 9 & 8 & 8 & 9 & 8.5 & 0.85 & Very good no objections \\
\hline 8. Niewęgłosz & 7.5 & 7 & 7.5 & 8 & 7.5 & 0.75 & Very good little objections \\
\hline 9. Obory & 9 & 8 & 7.5 & 9 & 8.375 & 0.84 & Very good no objections \\
\hline 10. Dąbrowa Lazy & 9 & 8 & 8 & 9 & 8.5 & 0.85 & Very good no objections \\
\hline
\end{tabular}

Explanations: $B_{L Z}{ }^{1)}-$ safety and working conditions of people and animals, $O_{s}^{2)}$ - environmental protection, $U_{o}^{3)}$ - arduousness of service, $D_{z}^{4)}-$ animal living conditions 
around a dunghill, technical condition of tanks, etc.) - from 7 to 8.5 and animal welfare - from 8 to 9 points. Of all the analyzed features the lowest rating was given for labor arduousness - from 7.5 to 8 points.

Technical examination of dunghills, in the 10 selected farms focused on milk production (most of the winners of "Golden Topping"), proved that 7 of them meet the dunghills requirements without objections and 3 require decisive actions to improve conditions for the storage of manure and liquid wastes, including improving safety conditions.

The relationship between the level of mechanization of disposal and storage of manure treatments and its functionality index was also examined. It was found that there is a clear relationship between the functionality index and the level of mechanization. Barns located on the fourth and fifth (very high) levels of mechanization, achieved the highest scores in the assessments, which clearly proves that the relationship exists (Fig. 3).

On the basis of the results concerning relation between the functionality index and the mechanization level it is dis- played that there is the relatively strong positive correlation between two analyzed factors with a correlation coefficient $r=$ $=0.571246, p=0.0845(p<0.10)$, at the level of determination $\mathrm{R}^{2}=32.6321 \%$, standard error of estimation $=0.449559$ and the value of Student's t-test $=1.96853$ (Fig. 3). This relation clearly indicates that as the mechanization level of manure removal process increases the functionality index of removing and storing manure treatment rises.

Romaniuk (1996) investigated the functionality of the cattle barns in terms of all treatments and came to the same conclusion. He stated that presented relation speaks in favor of mechanization of milk production in specialized farms. In case of manure disposal and storage treatments the environmental protection, safety and working conditions have a significant impact on the value of the functionality index and the relation to the mechanization level of the analyzed cattle-barns. It is clearly visible in case of the objects nr 3 and $\mathrm{nr} 8$, where deficiencies in these particular features in relation to other objects decreased the final score for functionality index.

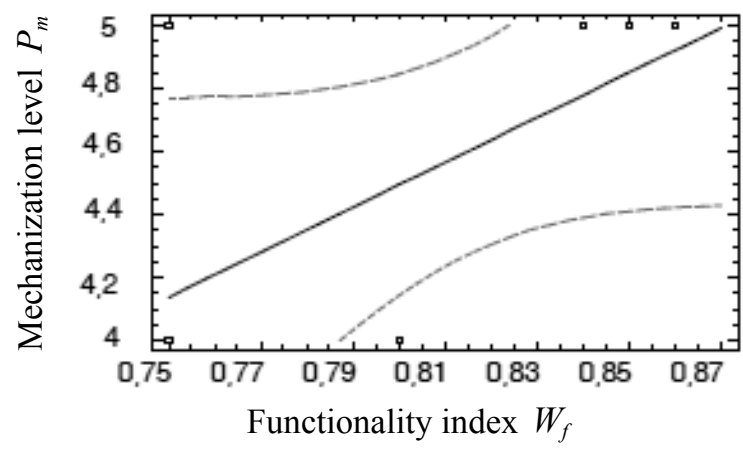

$r=0.571246$

$\mathrm{R}^{2}=32.6321 \%$

Standard Error of Est. $=0449559$

$\mathrm{t}$-Student $=1.96853$

$p=0.0845(p>0.10)$

regression equation

$y=-1.20259+7.11974 x$

$\mathrm{n}=10$

FIGURE 3. Diagram of the regression determining relation of mechanization level $P m$ and functionality index $W_{f}$, according to linear function $Y=a+b X$ 


\section{CONCLUSIONS}

1. On the basis of conducted studies it can be stated that facilities for storage of natural fertilizers which were designed and constructed in accordance with the requirements of law and the art of building present a very low threat to the environment.

2. Proper operation of dunghills and especially prevention of the manure running outside of the storage place are of great importance in terms of environmental protection.

3. An important but neglected principle is to provide proper safety zones around the reservoirs for liquid manure, thereby ensuring the safety of workers, animals and other people staying at the farm.

4. Use of the functionality index of disposal and storage of manure treatments allows to assessing the impact of manure storages on the environment.

5. The relation that exists between the functionality index and the mechanization level indicates that there is the relatively strong positive correlation between them, with the correlation coefficient $r=0.571246, p=0.0845$ $(\mathrm{p}<0.10)$ and with a level of determination $\mathrm{R}^{2}=32.6321 \%$, which leads to the conclusion that as the level of mechanization increases the functionality index of disposal and storage of manure is also being increased.

\section{REFERENCES}

COUNCIL DIRECTIVE of 12 December 1991 concerning the protection of waters against pollution caused by nitrates from agricultural sources (91/676/EEC).

COUNCIL DIRECTIVE of 24 September 1996 concerning integrated pollution prevention and control (96/61/EC).
DzU $2007 \mathrm{nr} 147$ poz. 1033. Ustawa z dnia 10 lipca 2007 r. o nawozach i nawożeniu [The Fertilizers and Fertilization Act].

FIEDOROWICZ G. 1998: Efektywność chowu krów w oborach o różnych wielkościach i rozwiązaniach technologicznych, [The effectiveness of cows breeding in the barns of various sizes and technological solutions], Rozprawa habilitacyjna, IBMER, Warszawa.

ROMANIUK W. 1996: Wpływ funkcjonalno-technologicznych rozwiązań obór na energochłonność i koszty produkcji mleka w gospodarstwach rodzinnych, [The impact of functional and technological solutions on the energy consumption of barns and the cost of milk production in family farms], Rozprawa habilitacyjna, Prace Naukowo-Badawcze IBMER, Warszawa.

WARDAL W., GŁASZCZKA A. 2005: Przepisy Unii Europejskiej. Jak postępować z nawozami naturalnymi? [The European Union Legislation. How to deal with manure?] Technika Rolnicza, Ogrodnicza, Leśna, 9-10, p. 31-32.

WIERZBICKI K., RUDNIK K., SADOWSKA M., JÓŹWIKOWSKI T., PALMOWSKI J. 2002: Wybrane obiekty infrastruktury technicznej obszarów wiejskich. [Selected objects of technical infrastructure of rural areas] IBMER, Warszawa.

WIŚNIEWSKI K. 2007: Nakłady energetyczne $w$ technologii usuwania i magazynowania nawozów naturalnych w ściółkowych obór wolnostanowiskowych, [Energy inputs in the removal and storage of natural fertilizers technologies in littered free-stall cattle barns]. Praca doktorska, IBMER, Warszawa.

WIŚNIEWSKI K. 2008: Miejsce na gnojownię, Budowlano-remontowy poradnik rolnika, [Place for the dunghill, Construction and repair guide for a farmer], maj 2008 Murator.

Streszczenie: Techniczne i funkcjonalne aspekty wykonywania magazynów nawozów naturalnych pod względem ochrony środowiska. W artykule poruszono sprawy związane z wykonaniem i użytkowaniem magazynów nawozów naturalnych $\mathrm{w}$ aspekcie ochrony środowiska. Uwzględniono dwa podstawowe czynniki wpływające na prawidłowe funkcjonowanie magazynów nawozów naturalnych: czynniki techniczne i czynniki organizacyjne. W przypadku aspektów technicznych wykonania i użytkowania magazynów nawozów 
naturalnych istotne znaczenie ma przestrzeganie zasad BAT. Natomiast w przypadku czynników organizacyjnych na pierwszy plan wysuwa się przestrzeganie przepisów prawa polskiego i Unii Europejskiej.

MS. received October 2011

\section{Authors' address:}

Krzysztof Wiśniewski, Agata Pawłat-Zawrzykraj

Katedra Inżynierii Budowlanej

Szkoła Główna Gospodarstwa Wiejskiego

ul. Nowoursynowska 159

02-786 Warszawa

Poland 